\title{
Quidditas
}

\section{The Myth of the Persecuted Female Healer}

Jane P. Davidson

University of Nevada

Follow this and additional works at: https://scholarsarchive.byu.edu/rmmra

Part of the Comparative Literature Commons, History Commons, Philosophy Commons, and the Renaissance Studies Commons

\section{Recommended Citation}

Davidson, Jane P. (1993) "The Myth of the Persecuted Female Healer," Quidditas: Vol. 14 , Article 9. Available at: https://scholarsarchive.byu.edu/rmmra/vol14/iss1/9

This Article is brought to you for free and open access by the Journals at BYU ScholarsArchive. It has been accepted for inclusion in Quidditas by an authorized editor of BYU ScholarsArchive. For more information, please contact scholarsarchive@byu.edu, ellen_amatangelo@byu.edu. 


\title{
The Myth of the Persecuted Female Healer
}

\author{
Jane P. Davidson \\ University of Nevada
}

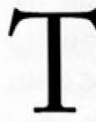

The idea that most women condemned as witches during the classic periods of witch persecution in Europe (between 1500 and 1700) were in actuality unlicensed healers who were suppressed by the male medical establishment arose among feminist writers, historians, and religious leaders. This idea has been around for more than twenty years now and has become a familiar strain in women's studies. It has been presented often as historically valid by scholars of both genders. The theory is that the midwife, the 'cunning woman', and the female folk herbalist were condemned as witches by male physicians in order to keep these women in their places - that is, out of organized medicine. Consequently, according to these claims, witchcraft persecutions were not just a religious phenomenon, but in reality often a misogynist conspiracy with both societal and economic overtones. In 1971 Thomas Szasz, in The Manufacture of Madness, wrote:

Because the Medieval Church ... controlled medical education and practice, the Inquisition [witch-hunts] constitutes, among other things, an early instance of the 'professional' repudiating the skills and interfering with the rights of the 'nonprofessional' to minister to the poor.

There is no need to agree with this feminist interpretation of the witch persecutions. In fact, the historical evidence concerning European witchcraft which is derived from accounts and transcripts of trials and other forms

'Thomas Szasz is quoted in Barbara Ehrenreich and Deirdre English, Witchcraft and Medicine in the Middle Ages (Feminist Press at the City University of New York, New York 1971) p 6.

This rather amazing small study was written by two nurses whose points of view reflect very strong feminist opinions. They admit that their sources were 'usually sketchy and often biased', but I do not believe that the authors realize the extent of their own biases as they wrote. This study is typical of the strident feminist position toward the supposed conspiracy of male medical professionals. 
of primary literature fails to support such a theory. On the contrary, the actual historical evidence shows that female healers, with the exception of midwives, were rarely those denounced as witches. While the belief that midwives were witches was widespread, evidence indicates that even the number of practicing midwives that were tried and condemned is not particularly large. Thus, the concept that midwives were witches or witches were midwives appears to be as reliable as the concept that witches flew to sabbaths on the backs of goats or on broomsticks.

The time for a serious and unbiased scholarly discourse on the question of female healers as witches is considerably overdue. In this essay I will discuss several cases of female 'healers' who were persecuted as witches in the period of classic witch-hunts - the period some feminists call 'the Burning Times'. These women's stories appear both in contemporaneous literature and art. I will also briefly review the historical record and the opinions of some contemporaries of the 'witches'.

Historical data does not support an interpretation such as the following:

Witches lived and were burned long before the development of modern medical technology. The great majority of them were lay healers serving the peasant population, and their suppression marks one of the opening struggles in the history of man's suppression of women as healers. ... The women's health movement of today has ancient roots in the medieval covens, and its opponents have as their ancestors those who ruthlessly forced the elimination of witches. ${ }^{2}$

To posit that there were such organizations as 'medieval covens' or that there was an ancient 'women's health movement' is highly speculative at best and specious at worst. ${ }^{3}$ The evidence that survives of reputed organized groups of witches comes from trial accounts and confessions. These accounts were regularly coerced from the accused via torture and were suggested to her or him through a list of leading questions routinely asked all suspected witches. There is little reason to believe anything that the accused reported as a result of such treatments. To extrapolate from such confessions that

${ }^{2}$ Ibid.

${ }^{3}$ Certainly it was believed that there were groups of organized satanist witches, and sometimes these groups bore the title of 'coven'. For example, a trial account of the Scottish witch Bessie Dunlop from 1576 discusses the group of witches to which she belonged; however, it does not include the word coven. Another trial account for Isabel Gowdie, also a Scot, dates from 1662 . This account does use the word coven to describe witches groups. However, the evidence given in witches' confessions is always subject to considerable doubt as to its actual validity, so while the word coven entered the English language it did not necessarily mean that such organizations were extant. (See Thomas D. Davidson, Rowan Tree and Red Thread [Edinburgh 1949], for examples of the uses of the term coven in Scotland.) 
there were such things as witches' covens, witches' meetings, witches who worried about women's health, or even witches at all is to create very flimsy history indeed. It does no good to quote the Malleus Maleficarum concerning evil midwives unless there is evidence to demonstrate that these midwives were indeed killers of mothers and children; without such evidence it is pointless to write:

The witch-hunts left a lasting effect: An aspect of the female has ever since been associated with the witch, and an aura of contamination has remained - especially around the midwife and other women healers. This early and devastating exclusion of women from independent healing roles was a violent precedent. ${ }^{4}$

It is true that there were statutes such as the English act of 1512 that limited the practice of medicine to persons who had graduated from Oxford or Cambridge. Such statutes are routinely referenced as examples of officially sponsored suppression of women healers. But it is also true that in 1542 Parliament passed another act which stated that 'divers honest men and women' could practice medicine. ${ }^{5}$ The operative requirement here was

"Ehrenreich and English, Witchcraft and Medicine p 6.

'See, for example, Hilary Bourdillon, Women as Healers: A History of Women and Medicine (Cambridge University Press, New York 1988) p 19, for such a discussion of various acts of Parliament. Bourdillon writes from a feminist perspective, but one much more balanced than that of Ehrenreich and English.

The myth of the female witch healer also affects the thinking of many nonhistorians who write about the classic period of witcheraft persecutions. I think that this phenomenon makes all the more interesting a study of how widely spread this theory has become. For instance, the theory of women healers being persecuted as witches has permeated the thinking of many wiccans. It is a belief commonly held among those wiccans who are strong feminists. It is also occasionally found in the writings of other modern wiccans who may not profess to be feminists. Wiccan members consider themselves modern pagans and sometimes call themselves 'witches'. There are a large number of different groups of wiccans, not all of whom are satanists. Some of the groups are all females and are strongly feminist, others are confined exclusively to members who are male homosexuals, others admit members of both genders. There are also wiccans who do not belong to any organized group. Their literature, made up of amateur history and folklore, frequently discusses the persecutions of historical witches who were believed by their contemporaries to be satanists. It is common in wiccan literature to read about the terrorism practiced against the historic witches whom wiccans generally believe to have been their religious predecessors. Many wiccans maintain that these old witches were pagans, but not satanists. They sometimes also state that the old witches were folk healers being persecuted by the church and the legal establishments of various European states. These persons tend to inveigh against the persecution of witches by Christian religious authorities and not to center their discussions on the notion of medical professionals who were intent on defending their territory against women. However, it is not unheard of to find feminist literature such as the work of Ehrenreich and English for sale in wiccan bookshops. A recent cata$\log$ put out by Enchantments, a wiccan bookstore in New York City, contains a listing for a pamphlet written by Barbara Ehrenreich entitled Witches, Midwives and Nurses. This 
that the persons who could practice medicine had to be 'honest'. The act is inclusive of women, not exclusive.

If the witches were in reality female healers whose only crime was that of economic conflict with the male medical establishment, then where in this scenario should the case of a male physician who was condemned as a witch be placed? In other words, what should we do with Dr Lambe?

The infamous Dr. Lambe started life as a teacher of English, his pupils being the children of gentlemen. It is possible that he possessed some powers of clairvoyance and thought-reading, and was reputed to be an entertaining juggler, whilst also practicing as a physician. He became in fact the typical wise man or wizard, helping people to find lost goods, advising them in family troubles and foretelling the future.

There are several extant legal documents and a contemporary popular pamphlet concerning the case of Dr Lambe. Dr Lambe was indicted for witchcraft several times between 1607 and 1610 . He was imprisoned in Worcestershire but was removed to King's Bench Prison in London, apparently because it was felt that he had bewitched the jailers, the sheriff, the foreman of the jury that had convicted him, and even some of

pamphlet recapitulates the typical feminist propaganda about the persecution of women healers throughout history. A strongly feminist wiccan book by Z. Budapest, The Holy Book of Women's Mysteries (Oakland, Cal 1989) also lists Ehrenreich and English in its bibliography, although Budapest does not emphasize in particular the role of female healers as persecuted 'witches'.

Vivianne Crowley, a modern wiccan who is not a feminist, but rather has a Jungian analysis orientation to her beliefs, writes that 'the Gods of Wicca are not jealous Gods. We therefore worship the personification of the male and female principle, the God and the Goddess' (Wicca [Aquarian Press, 1989] p 11).

However, Crowley goes on to discuss historical witches in England in a manner that makes clear she believes some female medical practitioners had been persecuted: In England, while large-scale organized Paganism had been fairly successfully suppressed by the Church, the craft of magic was preserved in the villages of England by particular families of "witches", “cunning men" and "wise women"' (p 48).

The interesting thing about this last statement concerning English witches is that Crowley mentions both male and female healers. This inclusion of male healers obviously touches upon the central issue of the validity of the female witch heroine myth. The emphasis is thereby shifted from the traditional idea that male doctors attacked 'uppity' unlicensed females. I have read extensively in wiccan literature, including feminist wiccan literature. I cannot find a specific cited example of the conspiracy of doctors versus unlicensed women. It seems that the wiccans have focused on the idea of the folk healers' being persecuted by the other establishments that I have mentioned rather than on a doctors' conspiracy.

'C. L'Estrange Ewen, Witchcraft and Demonianism (1933; repr Barnes and Noble, New York 1970) p 202. 
the justices who had heard his case. ${ }^{7}$ In the London jail Dr Lambe continued to see clients, who included the duke of Buckingham. Besides being identified as a witch, Dr Lambe had an equally bad reputation as a pederast and a rapist. In 1628 he was attacked on the street by a London mob and beaten to death.

Dr Lambe's case is associated with that of an incident of a female healer tried for witchcraft - the case of Anne Bodenham. Both servant and mistress to Dr Lambe during his residence in London, she learned her healing arts and supposedly her witchcraft from him.

Anne Bodenham, a clairvoyant who lived into her eighties, became a cause celebre. She is the subject of two pamphlets published in 1653, immediately after her execution. Her infamy persisted and in 1688 she appears in Nathaniel Crouch's The Kingdom of Darkness, a collection of fantastic tales that concern, among other things, the supernatural. One might compare The Kingdom of Darkness to today's tabloid journalism. Crouch (1632?-1725?) tells stories of witches, ghosts, and demonic possessions. $\mathrm{He}$ repeats the stories of Anne Bodenham's deeds as told by the pamphlets. Anne is described as being engaged in much the same occult occupations as Dr Lambe. She is depicted as a 'cunning woman'. She is accused of curing diseases by means of witchcraft, utilizing charms and spells. ${ }^{8}$ While these tales do mention Anne's ability to cure disease, they maintain that she, like Dr Lambe, apparently did this through magic or witchcraft rather than through medical skill. She was condemned as a malefactor rather than as a healer. No consideration is given to the fact that she was an unlicensed healer.

Anne Bodenham is one of only a few witches who are specifically described in historical documents as healers or 'cunning women'. The story Crouch selected to emphasize tells of Anne Bodenham's conjuring of devils and her attempt to entice her maid into witchcraft, not of her 'medical' ability. Crouch quoted almost directly from what he obviously considered a very titillating section of one of the 1653 pamphlets.

'Ibid. First published in 1933, this was a pioneering study of the documents concerning English witchcraft trials. It is still useful for its many transcriptions of trial accounts. Even though this is a very old source, I deliberately selected examples from it. I did this to show that the evidence that witches were not usually listed by profession or occupation has been readily available for the last sixty years. Any number of more recent studies for the British Isles and other nations in Europe, such as the works of Middlefort, Monter, Kieckhefer, Larner, Muchembled, Henningson and Ankarloo, Dupont-Bouchat, and many others, demonstrate the same types of data concerning the supposed occupations of female witches.

${ }^{8} I$ bid pp 202-4. 


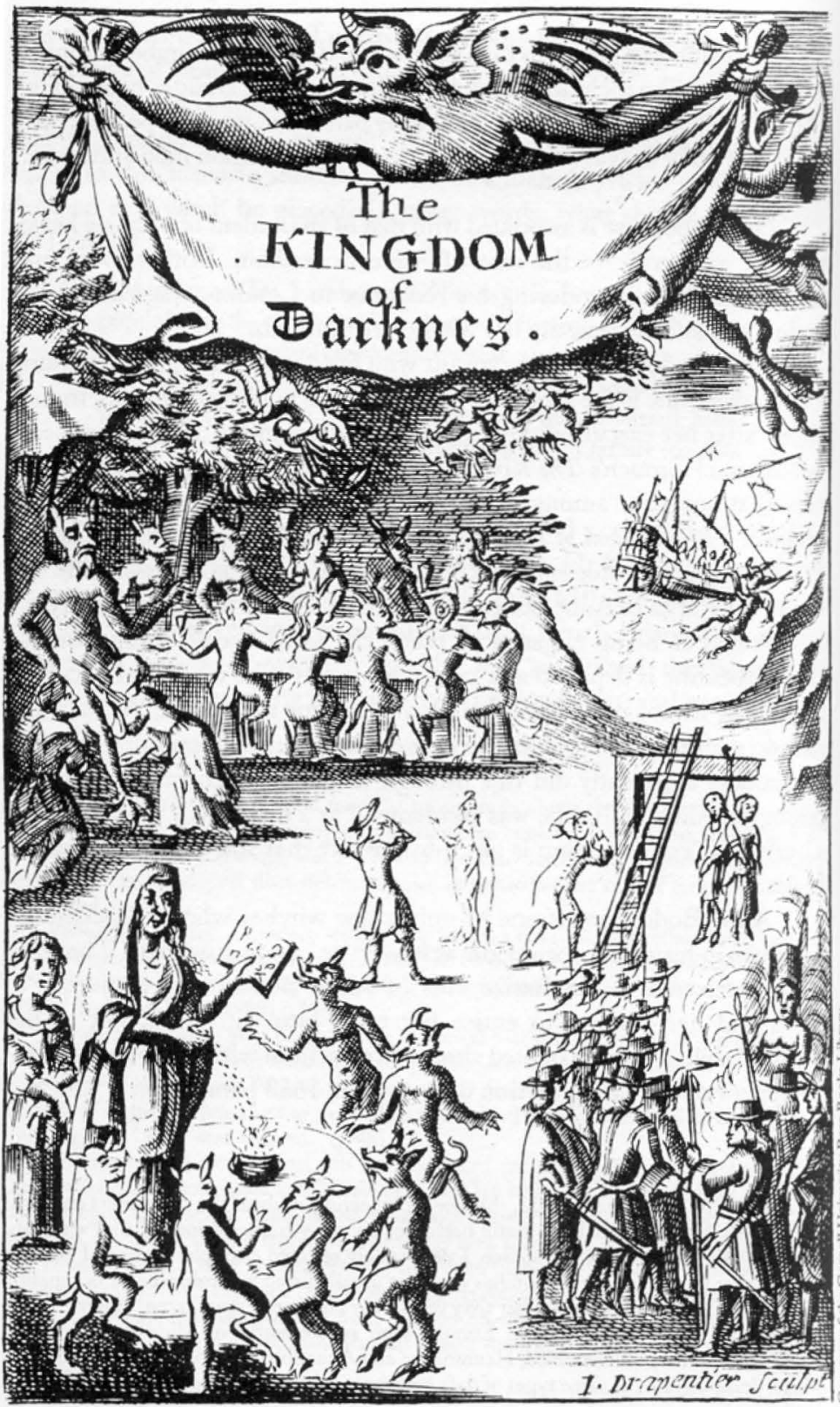

The Kingdom of Darkness frontispiece 


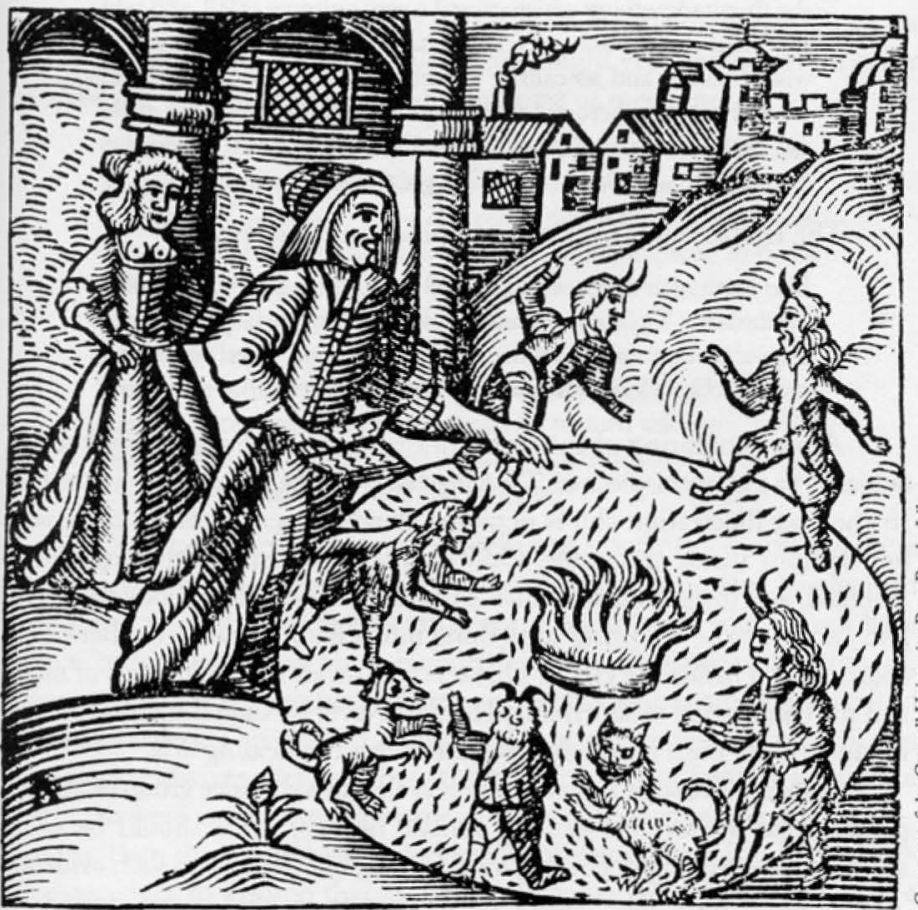

The Kingdom of Darkness text illustration 
[Anne Bodenham] ... took her staff and therewith drew a circle about the house and then took a book carrying it over to the circle with her hands, after that she laid a green glass on the book, and placed within the circle an earthen pot of coals wherein she threw something which caused a very noisome smell, and told the maid she should not fear whatever happened for now they would come, and so calling Belzebub, Tormentor, Satan and Lucifer appear, there suddenly arose a very high wind that made the house shake, and presently the back door flying open came five spirits ... [ [who looked like] great boys. ${ }^{9}$

The trial account from the pamphlet runs this way:

She forthwith made a circle, and looking in her book, called Beelzebub, Tormentor, Lucifer and Satan [to] appear, then appeared two spirits in the likeness of great boys, with long shagged black hair, and stood by her looking over her shoulder. ${ }^{10}$

Anne's conjuring of the devils in the shape of shaggy-haired boys is depicted in the frontispiece of The Kingdom of Darkness and again in the text. In the text illustration she is depicted standing near a magic circle with her demons inside the circle. Oddly, in the frontispiece the situation is reversed, and instead Anne is inside the circle. She holds a book of charms and appears to be throwing something into a flaming cauldron, her 'pot of coals', placed inside the circle. This set of illustrations depicts acts of magic and the conjuration of supernatural beings. Never is Anne Bodenham shown in any activity even remotely associated with the healing arts.

If there were such a phenomenon as that of a cohesive group of learned professional doctors persecuting female healers, there should be widespread substantiating documentary evidence, but there is no such evidence. Those who study the history of witchcraft in the classic periods of European persecution will attest to the fact that there is a tremendous amount of extant primary evidence concerning trials, as well as popular and learned beliefs. Relatively modern historical research in this enormous amount of material has been ongoing for at least the last one hundred years. Such a concept as doctors 'ganging up' to persecute women healers, or even women midwives, just does not appear in the many hundreds of examples of witchcraft literature published during the periods of classic persecution. Some of this literature was written by doctors. The famous sixteenth-century German physician Johannes Weyer (1515-1588) took the opposite stance

'Nathaniel Crouch, The Kingdom of Darkness (London 1670), probably published by the author. The text is taken directly from Crouch.

${ }^{10}$ Ewen, Witchcraft and Demonianism pp 324-9 for the text of the trial account pamphlet. 
and made fun of unlearned or poorly trained doctors who were so ignorant of medicine and the normal courses of diseases that they proclaimed witches to be at work whenever they could not cure an individual. He accused them not only of ignorance and superstition but also of attempting to use witchcraft as an excuse to avoid being sued for malpractice. He never mentioned the concept that a male doctor might yell 'witchcraft' in order to prevent a woman from practicing any type of medicine:

Meanwhile I do not deny that the one refuge of some incompetent persons who shamelessly and deviously boast of an understanding of medicine - the one refuge when they do not know the nature of an illness, far less its cure, and are forced to make their decisions like blind men judging colors - is to assert at once that it is a case of witchcraft. Under this cloak they cunningly cover up their own ignorance in matters pertaining to the hallowed art of medicine. ... By referring to evil-doing or witchcraft as a pretext, they strive carefully to turn aside malicious accusations, or rather legal actions justly instituted against them - they who are truly the evil-doers ${ }^{11}$

Just as there is not historical evidence of a doctors' conspiracy, there are also very few documented instances of female healers who were condemned as witches. Since the late nineteenth century, hundreds of trial records have been examined and transcribed. Hundreds of women's names have surfaced; however, only a small number of European witches were specifically described as female healers. This number is expanded somewhat if one includes witches who were midwives. Yet even here the vast majority of females accused of witchcraft were merely listed by name or as the wife of so and so. Their occupations, even that of midwifery, were generally not given. It is bad historical procedure to assume that every female witch was either a healer or a midwife when there is not evidence to establish this. To do this is equivalent to accepting the very beliefs about witches that were popularized in the religious, legal, and medical literature of the times. These books demonstrate that ignorance and superstition were by no means excluded from such forms of literature. Since beliefs about witches were held to be religious dogma, many authors tended to accept them unquestioningly, at least in print. Those who dared to doubt in public the validity of witchcraft were in danger of persecution themselves. While we may be able to deduce a specific author's opinions about witchcraft from an individual piece of literature, it is still bad historical scholarship to read Renaissance and seventeenth- 
century authors (who routinely cited previous 'authorities' for their stories about how witches behaved) and then assume that such writings reflect actual historical facts concerning specific individuals who were brought to trial. The 'cunning women' - that is, women healers who were not specifically designated as midwives, but usually as herbalists - are in fact a curious lot. British historian C. L'Estrange Ewen, who over sixty years ago compiled hundreds of trial accounts for the British Isles, discovered that witches were believed to have the ability to counteract each other's witchcraft; that is, some did good witchcraft instead of bad witchcraft.

Generally speaking, neither in prison nor out had the witches any skill to counteract mischief once accomplished, although sometimes one practitioner could nullify and amend the evil work of another. . . . Thus Elizabeth Stile (1580) having turned back a child's hand, Mother Dutten restored it to the normal position. ... The boy of Droitwich recovered his speech, upon receiving the blessing of the witch who had caused his dumbness.... Goodwife Orchard (1659) partially cured the ensorcelled maid who accused her. ... A sick child recovered after Elizabeth Lambe had asked her forgiveness ... and a confession forced from Agnes Samuel resulted in the immediate relief to the Throckmorton children. $^{12}$

When one examines the trial accounts of these women one finds that with respect to the English cases cited by Ewen, Elizabeth Stile was not listed as having an occupation, nor was Mother Dutten. The elderly woman who bewitched and then reversed her curse on the boy from Droitwich was described only as an old woman whom the boy encountered. Goody Orchard was a malicious old woman, but not referred to as a healer or midwife. No occupation was listed for Elizabeth Lambe. And finally Agnes Samuel comes closest in this group to having some role as a healer'. She was employed in the Throckmorton house as a 'serving maid or nurse'. She possibly might have had the opportunity to administer some sort of folk medicine, but the trial account does not say that. It describes the woman pronouncing what sound like exorcisms over one bewitched child, scratching another in order to heal him, and so forth. It does not describe her as having given anyone any medications or foodstuff. ${ }^{13}$

The important point here is not that these witches were healers, licensed or otherwise, but that they could practice magic or witchcraft

${ }^{12}$ For the trial accounts of these witches, see Ewen, Witchcraft and Demonianism pp 104, $153,316,335,396,170$ respectively.

${ }^{13}$ See n 12 above. 
for good or for evil. Such healers were being condemned for working charms rather than attempting to practice established forms of professional medicine. Seventeenth-century Scottish criminal law comments upon such cases:

[Healing with charms] cannot be produced without the Devil and that he will not employ himself at the desire of any who have not resigned themselves wholly to him, it is very just that the users of these [charms] should be punished being guilty at least of apostasy and heresy. ${ }^{14}$

Some feminist writers have agreed with this position and rightly pointed out that the 'Church saw its attack on peasant healers as an attack on magic, not medicine'. ${ }^{15}$ This was a centuries-old position that went back at least as far as the eighth century. A penitential that may date from the eighth century and that is ascribed by some to the Venerable Bede, who speaks of a penance of five years for a 'woman ... who places her child upon a roof or in an oven in order to cure a fever'. ${ }^{16}$ The German cleric Burchard of Worms (d. 1025) also speaks of the incorrect and sinful use of charms or superstitious beliefs in curing. Burchard's penitential, The Corrector of Burchard of Worms, was written about $1008-1012$ as part of a larger theological work, the Decretorum. It is rightly esteemed as a great source of both the religious and the folk beliefs of this period. Burchard has the confessor ask the following of his penitent:

Hast thou done what some do when they are visiting the sick person? When they approach the house where the sick person lies if they find a stone lying nearby they turn the stone over and look in the place where the stone was lying [to see] if there is anything living under it. ... [If there is] then they aver that the sick person will recover. ... Hast thou collected medicinal herbs with evil incantations not with the creed and the Lord's prayer that is with the singing of the 'credo in Deum' or the paternoster? ? $^{17}$

"See a law from 1678 quoted in Dan McKenzie, The Infancy of Medicine (London 1927).

${ }^{15}$ Ehrenreich and English, Witchcraft and Medicine $\mathrm{p} 13$.

"For the quotation ascribed to the Venerable Bede, see J. T. McNeill and H. M. Gamer, Medieval Handbooks of Penance (New York 1965) p 229.

"For the quotations from the Corrector of Burchard of Worms, see McNeill and Gamer, Medieval Handbooks of Penance pp 335, 330. See also Migne, Patrologia Latina (1853) vol $140 \mathrm{p} 962$ for the quotation concerning gathering herbs with proper prayers: 'Collegisti herbas medicinales, cum aliis incantationibus cum symbolo et Dominica oratione, id est cum Credo in Deum et Pater noster cantando. The passage from the Corrector in question may also be this, Migne $\mathrm{p}$ 836: Non licet in collectione herbarum medicinalium aliquas observationes vel indivino, et Oratione Dominica, ut Deus et Dominus noster bonoretur: 
But what do clerical attacks such as those of Burchard have to do with the mythical conspiracy of doctors against women?

Five hundred years after Burchard of Worms, Johannes Weyer again comments stridently against those persons who used magical or superstitious cures for disease while working with charms or magical sounding sayings:

Here we should mention the monstrous employment of superstitions and unknown words wherein you cannot tell whether you are praying for good or for evil.... I know a gentleman of high station who is famed for a similar type of cure. He writes 'hax pax max Deus adimax' upon an apple slice and then gives it as food to a person infected by a rabid dog. ... These words are corrupted because of ignorance.... The nobleman probably read a piece in German and discovered that the Latin words hoc+po+mo+ Deus adiuvet+ ['May God help you by means of this apple'] were effective for a cure of this sort. ${ }^{18}$

Weyer went on to explain that the man was so ignorant of Latin that he misunderstood an indication to make the Sign of the Cross at the end of each word for the letter $\mathrm{x}$.

To ascertain whether there was a doctors' conspiracy against women who wanted to practice healing arts is a slightly different research problem. Witchcraft literature from the period of the persecutions indicates that the idea that witches murdered children was a widely held belief and undoubtedly a part of both learned and popular culture. Often, these witches were believed to be midwives. One finds this concept in the Malleus Maleficarum (bk 1 q 9), where the subject of midwives has a whole chapter, and in earlier witchcraft literature. Johannes Nider's Formicarius, written between 1435 and 1437 during the Council of Basle and printed about 1475, states that witches killed infants and ate their flesh (chap 5 c 3). Martin le Franc's poem, Le Champion des Dames, written about 1440 , also states that witches killed

See also Migne p 965 for the quotation concerning divination of the patient's future health by means of finding a fly or an ant under a stone: 'Fecisti quod quidam faciunt, dum visitant aliquem infirmum: cum appropinquaverint domui ubi infirmus decumbit, si invenerint aliquem lapidem juxta jacentem, revolvunt lapidem, et requirunt in loco ubi jacebat lapis, si ibi sti aliquid subtus quod vivat, et si inverenint ibi lumbricum, aut muscam, aut formicam, aut aliquid quod se moveat, tunc affirmant aegrotum colvalescere. Si autem nibil ibi invenerent quod se moveat, dicunt esse moriturum'. In this same Decretorum, Burchard of Worms also discusses the superstitious practice of placing one's sick child in an oven or on the roof. (See Migne p 835): 'Ex poenitentiali Bedae presbyteri. Mulier si qua flium suum ponit supra tectum aut in fornacem pro sanitate febrium unum annum poeniteat'.

${ }^{18}$ See Weyer, De Prestiqiis demonum (MRTS ed) bk 5 chap 8 pp 387, 388. 
infants. ${ }^{19}$ But I have already noted that in spite of such literature, there are few documented examples of midwives tried as witches.

However, we can identify some witch midwives from historical documents. One of these was Walpurga Haussmannen from Dillingen, Germany, who was put to death in 1587 . She was accused of killing many children, as well as of bewitching numerous farm animals, chiefly cattle. A contemporaneous pamphlet tells of her trial and the accusations made against her. (Although such pamphlets were popular in Germany at the time, few have survived.) But even when we consider that she was by profession a midwife, the pamphlet is not illustrated with Walpurga's deeds as a healer or a midwife, but rather with a scene in which she is shown meeting the devil for the first time. The artist and the publisher emphasized her ensuing pact with the devil rather than her later deeds of maleficia. If it were so important to suppress witch midwives, would it not have been more logical for the printer of this pamphlet to have shown Walpurga killing babies?

What do such examples as the previous cases of witches indicate? The answer is simple. If one looks at the historical record for a medical conspiracy against women healers, such a conspiracy is not there. On the contrary some recent scholarship demonstrates that in fact women did play a recognized and an accepted role in medicine during the seventeenth century in England. An example is Doreen G. Nagy's Popular Medicine in Seventeenth-Century England, which focuses an entire chapter on 'Women's Role in Stuart Medicine'. More studies like this one are needed, studies in which facts backed by solid historical procedures are presented. Nagy writes:

Since most medical historians of the early modern period have written from the perspective of professional medicine, they have either completely ignored the role of ordinary women in the provision of medical services, or dismissed them with patronizing terms such as wise women, herb women, white witches, or simply old women, often implying that they were little better than quacks. . . . By contrast, it will be demonstrated that women played a central role in Stuart health care. Because of their gender, women were only very rarely found amongst the ranks of professional surgeons and physicians. As a result academic

${ }^{19}$ Martin le Franc was a secretary to the anti-pope Felix V. Le Champion des Dames, le Franc's poem, is easier to retrieve in modern transcriptions of French literature than are the works of Johannes Nider. Original and early editions of Nider's published works may be found at various rare books collections, including those of UCLA, Cornell University, and the University of Pennsylvania. For the comments of Nider and le Franc, the reader may readily consult transcriptions in C. H. Lea, Materials toward a History of Witchcraft (Philadelphia 1939; repr New York 1986) vol 1 passim. 


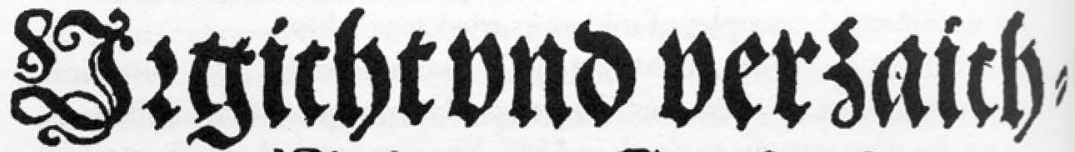

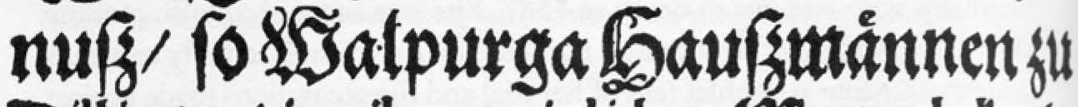
Dillingen/ intmiber peinlichen srzarter betand batt/ was fo für obels ond Jamers mit jhet 万et" ecey/ fo fy bif itt die 30, Jat getríbett/ attgerich ono geffiffe bat/mit 万ilf ond Kabt ibzes 2 ilt teuffels / fo ibe barzu gebolffen / Deld be Dalburga/21mo is 8>. Jar/bett

\section{October/ verbiantot ond gericht iff wotoen/zc.}
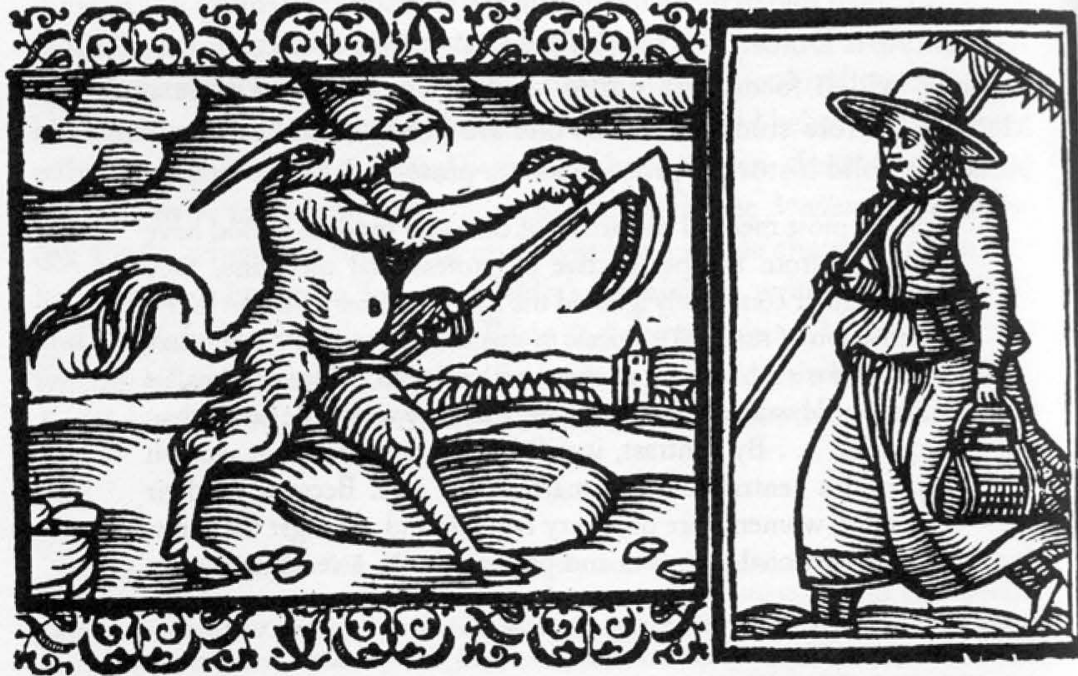

M, D, LXXXVIII 
studies have focussed on plotting the linear development of the medical profession. ... A case study of the role of women sheds considerable light upon the topic of popular medicine. ${ }^{20}$

Nagy discusses documented instances of women medical professionals and a number of cases of unlicensed women healers. Many of these examples are of gentlewomen who, unlike unlettered peasants, were able to write down and thus pass on medical formulations. Also, these women often treated persons of either gender. Nagy writes that the 'medical literature from the period indicates an acceptance of women's roles as nonprofessional medical practitioners and in some cases approval and encouragement from the professionals themselves'. ${ }^{21}$ This she can demonstrate from the data. This interpretation is in direct opposition to the theory that male medical professionals were trying to eradicate female healers by calling them witches and hauling them into court. In fact (just as I do not), Nagy does not believe that this conspiracy existed. She has written, 'While the general response of the typical physician was one of acceptance with regard to female nonlicensed practitioners ... a small group of medical reformers adopted a more positive attitude toward women healers'. ${ }^{22}$

Nagy's study is obviously important in that it does derive from the historical record, clearly reinforcing the evidence that can be taken from trial accounts. The problem with the woman's studies approach discussed in this essay is that these writers are applying a modern theory to the historical evidence, without paying the needed attention to what that evidence itself indicates.

${ }^{20}$ Doreen E. Nagy, Popular Medicine in Seventeenth-Century England (Bowling Green State University Popular Press, Bowling Green, Ohio 1988) p 54.

${ }^{21}$ Ibid $\mathrm{p} 74$.

${ }^{22}$ Ibid p 75. 